\title{
SUBSTANTIATION OF PHYTODESALINATION OF MINERALIZED WATERS IN FILTRATION-REGENERATION BIOPLATO
}

\author{
Bondar O.I. ${ }^{1}$, Fylypchuk V., ${ }^{2}$ Kuryliuk M. ${ }^{3}$, Krivoshei P. ${ }^{4}$ \\ State Ecological Academy of Postgraduate \\ Education and Management \\ 35, Metropolitan Vasyl Lipkivsky Str., 03035, Kyiv \\ National University of Water \\ and Environmental Engineering \\ 11, Soborna st., 33000, Rivne \\ ${ }^{3}$ Scientific-Production Enterprise \\ "Remvodplast plus" Ltd. \\ 3, Patrice Lumumba str., 01013, Kyiv \\ ${ }^{4}$ Company "Chandwin Project Pte." Ltd. \\ 101, Cecil Street, 069533, Singapore \\ dei2005@ukr.net; fylypchuk46@gmail.com; \\ atol.rosa@gmail.com; pavel@purewater.pw
}

\begin{abstract}
Filtration-regeneration bioplato can be used for complex purification and associated membrane-free phyto-desalination of mineralized water. Demineralization of water is carried out by the removal of salts of higher aquatic plants in the bioplate and treatment of circulation-regeneration water using coagulants, enzymes, bioreagents and probiotics, suspension of natural minerals with electrochemical activation of reagents. The treatment and purification unit of the circulation-regeneration water of the bioplate must include a flotation reactor-clarifier for flotation of the suspension, introduction of additional reagents and a self-cleaning foamed polystyrene filter with dosage in the clarified water of the bioreagent, which allows for a steady increase in green biomass and intensify salt extraction. To substantiate the possibility of concomitant desalination of mineralized waters with the help of higher aquatic plants, phytotechnology of filtration-regeneration bioplato of hydroponic type was used. Analyzed, that placing the bioplato at the end of the technological scheme allows to provide deep purification of water from organic and inorganic impurities and restore its natural properties through contact with higher aquatic plants. Also shown, the unit for treatment and purification of circulationregeneration waters of the bio-plato must include a flotation reactor-clarifier for introducing additional reagents and a self-washing foam polystyrene filter with dosage in clarified water of enzymes, bio-reagents and probiotics, which allows for a steady increase in green biomass and intensify the extraction of salts by higher aquatic plants. Key words: demineralization of water, the unit for treatment and purification of circulation-regeneration waters, filtration-regeneration bioplato.
\end{abstract}

Обгрунтування фітоопріснення мінералізованих вод у фільтраційно-регенераційних біоплато. Бондар О.І., Филипчук В.Л., Курилюк М.С., Кривошей П.П.

Фільтраційно-регенераційні біоплато можна використовувати для комплексного очищення та супутнього безмембранного фітоопріснення мінералізованих солонуватих вод. Демінералізація води здійснюється за рахунок вилучення солей вищими водними рослинами у біоплато та обробки циркуляційно-регенераційних вод з використанням коагулянтів, ензимів, біореагентів і пробіотиків, суспензії природних мінералів з електрохімічною активацією реагентів. Блок обробки та очищення циркуляційно-регенераційних вод біоплато повинен включати флотаційний реактор-прояснювач для флотації зависі, введення додаткових реагентів та самопромивний пінополістирольний фільтр з дозуванням у прояснену воду біореагентів, що дозволяє забезпечити постійний приріст зеленої біомаси вищих воднихрослин, інтенсифікувати фотосинтез і вилучення солей вищими водними рослинами. Для обгрунтування можливості супутнього опріснення мінералізованих вод за допомогою вищих водних рослин було використано фітотехнологію фільтраційно-регенераційного біоплато гідропонного типу. Розміщення біоплато в кінці технологічної схеми дозволяє забезпечити глибоке очищення води від органічних і неорганічних домішок і відновити ії природні властивості за рахунок контакту з вищими водними рослинами.Показано,що агрегат для очищення циркуляційно-регенераційних вод біоплато повинен містити флотаційний реактор-очисник для введення додаткових реагентів та самопромивний пінополістирольний фільтр з дозуванням у очищеній воді ферментів, біореагентів та пробіотиків, які дозволяє стабільно збільшувати зелену біомасу та інтенсифікувати видобуток солей вищими водними рослинами. Ключові слова: демінералізація води, агрегат для очищення циркуляційно-регенераційних вод, фільтраційно-регенераційне біоплато.

Introduction. The problem of salt water desalination is particularly acute in all countries of the world, especially in areas with limited fresh water supplies. Currently, the countries of Central Asia, the Middle East, the densely populated countries of Indonesia, China,
India and almost all countries in Africa and several countries in Europe, the Americas and the United States suffer from a lack of fresh water for agriculture and water supply and need an immediate solution to the shortage of clean water in coming soon. According to 
the UN, fresh water shortages worldwide are increasing by $13-20 \%$ annually and more than five billion people will have water problems already in 2050 [1]. The solution to the problem of ensuring access of the Earth's population to clean fresh water is the goal of all countries of the world without exception. The essential direction of the solution of this problem is the use in the drinking and technical water supply of mineralized water after their desalination to the statutory requirements, first of all, to the concentration of salts not higher than 1000 $1500 \mathrm{mg} / \mathrm{dm}^{3}$.

The current state of saltwater demineralization. The main methods of water desalination are reverse osmosis, ion exchange, evaporation (distillation), electrodialysis and combinations thereof. Currently, the most common methods of water desalination are reverse osmosis and ion exchange. Less commonly used are electrodialysis and distillation. In most cases, ion exchange allows the water to be desalinated to almost complete anion and cation extraction. For this purpose, water is passed successively through cation exchange and anion exchange filters and mixed action filters loaded with a mixture of anionite and cation exchanger. The number of filter stages and the type of ion-exchange material are determined by the depth of desalination of the water, the qualitative and quantitative composition of the impurities, and the requirements for the removal of contaminating ions. In most cases, ion exchange is recommended for the desalination of brackish water with an initial concentration of 1500 $2000 \mathrm{mg} / \mathrm{dm}^{3}$ [3], although some authors recommend more. The advantages of the ionic method include the high reliability of desalination. The disadvantages of this method are the large number of reagents for the periodic regeneration of ion exchangers, which leads to the discharge of waste regeneration solutions-eluates with a content of salts on average 2.0-3.0 greater than the mass of salts found in salty water [4]. A significant problem is the processing of these solutions, which are forbidden to discharge into water bodies.

In recent decades, the use of membrane processes such as reverse osmosis (hyperfiltration) has become widespread in water desalination. These processes reduce the salt content of mineralized water by filtration under pressure through special membranes. The salts are concentrated as concentrate or sent for further processing. Water pressure should be higher than the osmotic pressure of salts in water, which increases with increasing ion concentration. For example, if the osmotic pressure of drinking water reaches $0.10 \mathrm{MPa}$, then for seawater containing $35 \mathrm{~g} / \mathrm{dm}^{3}$ of salts, the osmotic pressure is a significant value of $2.58 \mathrm{MPa}$, which requires the use of high-pressure pumps. Output of desalinated water (permeate) reaches a maximum of $75 \%$ [5]. Multi-stage filtration is used to increase the efficiency of water desalination and to reduce the volume of waste concentrates. At high concentrations of salts, it is economically feasible to use two-stage desalting using reverse osmosis or electrodialysis in the first stage, and ion exchange in the second. Such a combined desalination scheme reduces the number of reagents and discharge concentrations of salts.

Compared to ion exchange purification and water desalination, reverse osmosis has the following advantages: process continuity and fewer reagents for membrane regeneration. However, it should be noted such disadvantages of this technology as the sensitivity of membranes to biological fouling, colloids, heavy metals and organic impurities, the formation of sediment insoluble salts on the surface of membranes, inlay of membranes with salts of rigidity and higher electricity costs. All this requires careful pre-disinfection and purification of water from the slurry, heavy metals and organic impurities that can "poison" the membranes. In addition, to prevent the deposition of insoluble compounds on the membrane surface special chemicals (sediment inhibitors or anti-scalants) are added to the source water.

In most cases, with significant desalination of large volumes of seawater, concentrated solutions of salts, together with anti-scalants and wash chemicals, are returned to the environment, which is extremely hazardous to the environment. The coastal ichthyofauna and coral reefs are especially affected by the discharge of concentrates after hyperfiltration into seawater. In particular, the United States Department of the Environment has found that the huge number of seawater desalination plants in the year has harmed more than 3.4 billion fishes and other marine fauna organisms and caused economic damages to the country's fishing industry in excess of 212,5 million \$. For a short period of time desalination plants can also destroy about $90 \%$ of plankton [6].

At present, there is a tendency to use natural methods for purification and conditioning of water using renewable natural resources, in particular through higher aquatic plants (HAP). From natural water treatment systems, bioengineering structures of the type of bioplato [7; 8], which are used for treatment of household, industrial wastewater, natural water in reservoirs and contaminated surface runoff are becoming widespread. The essence of the functioning of most bioplato is that phyto-purification of water in them occurs by filtration of water through the root system of HAP, due to photosynthesis in plants with ensuring their absorbing, cumulative, oxidizing and ability to synthesize oxygen in biodegradation of carbon dioxide. Enclosed hydroponic-type bioplato (EHTB) are quite common $[9,10]$, in which the root system of higher aquatic plants is fixed in a porous (gravel) filtration load and is constantly washed by water that moves vertically from top to bottom or bottom to top.

Along with the effective removal of slurry, organic impurities, biogenic nitrogen and phosphorus compounds, soluble salts are also removed from the water by higher aquatic plants. Thus, when using water hyacinth (Eichornia crassipes), along with sewage treatment 
from organic impurities on the biofilter (bioreactor), deletion of chloride up to $32 \%$, sulfate up to $43 \%$ was observed [11]. The reed at a yield of $44 \mathrm{t} / \mathrm{ha}$ of dry matter, can accumulate up to $419 \mathrm{~kg} / \mathrm{ha}$ of potassium, $408 \mathrm{~kg} / \mathrm{ha}$ of chlorides, $450 \mathrm{~kg} / \mathrm{ha}$ of sodium [12]. On bioengineered structures like Constructed Wetlands using higher aquatic plants, the efficiency of sulfate purification was up to $25-30 \%$, and sodium ions up to $10-15 \%[13]$.

At the same time, in the bioplato there is a gradual collimation of the pore space of the filter backfill, the inter-root space of the HAP and of the drainage by biofilm and mineralized sediment. In addition, there is a constant withering away of the roots of higher aquatic plants and algae, which further clogs backfill and drainage. These processes reduce the supply of oxygen and nutrients to the root system of HAP, which disrupts the processes of photosynthesis, transpiration and phyto-purification of water. As such bioplots do not allow sediment removal, then its accumulation and compaction begins in the filtration backfill and inter root space. Anaerobic biological processes begin to flow, resulting in reduced efficiency of mineral salts extraction, sorption and detoxification of organic impurities. Suffotic processes begin to flow, the multicomponent colloidal impurities are peptized and, as a consequence, secondary contamination of treated water is observed, higher aquatic plants die, and the efficiency and productivity of bioplate facilities is reduced.

As shown by the experimental data, the extraction of sulfates is at a high level up to 144 hours of operation of the facilities of the bioplato and is $0.404-0.837 \mathrm{mg} / \mathrm{h}$, then the absorption intensity drops to $0.121-0.046 \mathrm{mg} / \mathrm{h}$. [11]. The same is observed with the removal of chlorides. Periodic shutdown of facilities for repair and restoration work associated with the washing and regeneration of filter backfill and drainage is required to restore the bioplato operation, creates stress conditions for HAP and adversely affects the subsequent phyto-purification processes.

These disadvantages of the bioplato are absent when using filtration-regeneration hydroponic type bioplato (FRHTB) [14], which provides a constant flushing of the filter backfill, the root system of the HAP and drainage. The washing and regeneration of the bioplato is carried out by means of hydroautomated drainage of the special middle drainage of contaminated circulation-washing waters from the filtering backfill of the bioplato and their subsequent purification on a self-washing foamed polystyrene filter.

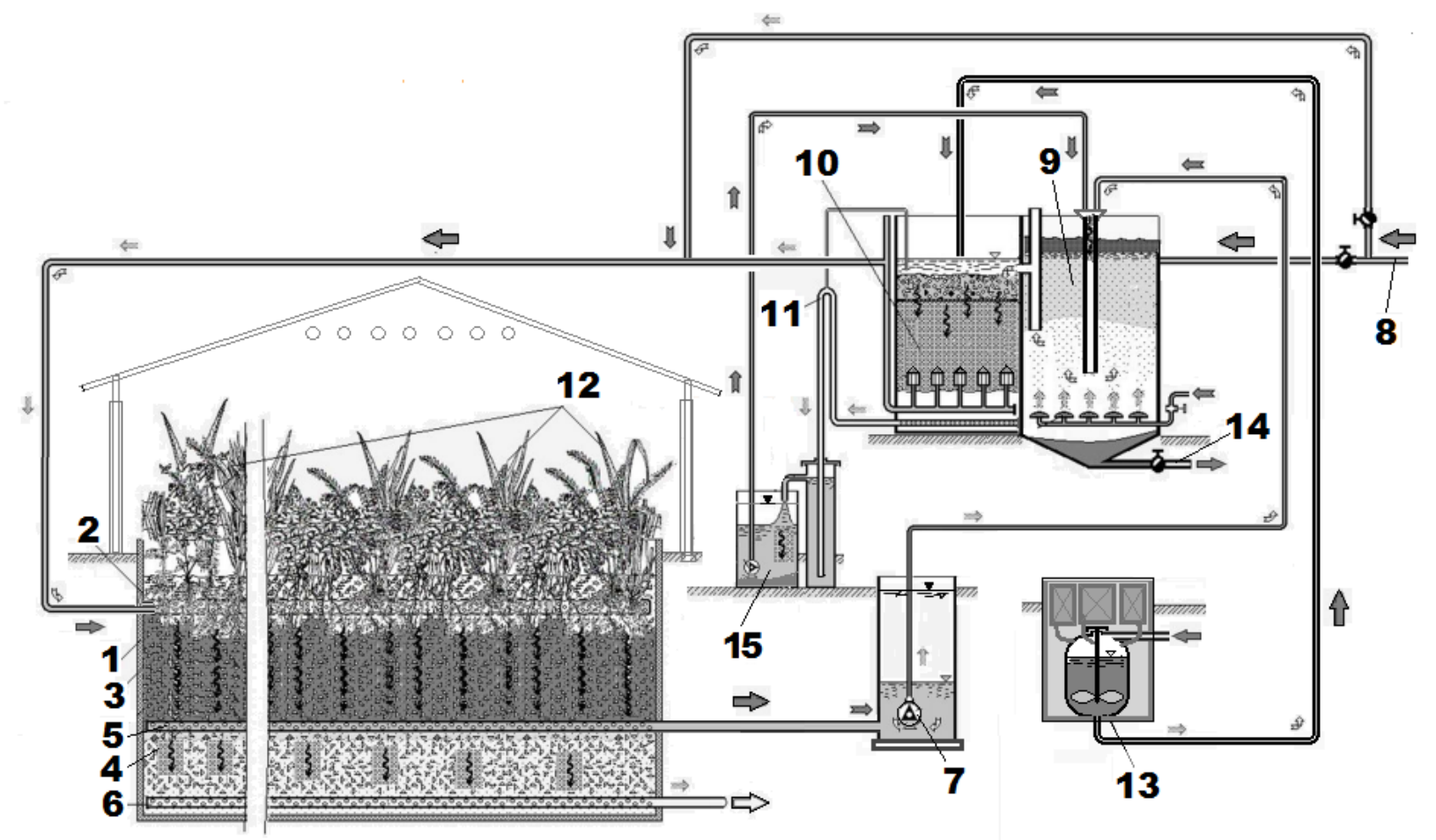

Fig. 1. Schematic diagram of filtration-regeneration bioplato of hydroponic type (FRHTB) for complex purification and desalination of mineralized waters

1-body bioplate, 2 - top drainage of water supply to the bioplato, 3 - top layer of filter backfill, 4 - bottom layer of filter backfill, 5 - medium drainage of collection and drainage of circulating-regeneration water, 6 - lower drainage of collection and drainage of purified water, 7 - pump of circulation-regeneration water, 8 - manifold of supply of source mineralized water for purification, 9 - flotation reactor-clarifier, 10 - self-flushing foam filter, 11 - unit hydro-automatic filter flushing, 12 - higher aquatic plants (HAP), 13 - reagent farm, 14 - sediment drainage, 15 - capacity for filter wash water accumulation 
It allows to provide self-healing mode of work of phytoconstructions of bioplato without creating stressful conditions for the growth of HAP on the bioplato. Thanks to the developed technology and design FRHTB mode of operation of the bioplato enables, regardless of the concentration of pollution in the source water, the cyclical filing of its treatment, availability of service personnel and in any climatic conditions to achieve higher quality and stability of water purification using higher aquatic plants. Therefore, the use of FRHTB for the complex removal of contaminants and salts from mineralized water can be promising in the case of unreacted and membrane-free water desalination.

The aim of this work is to analyze the treatment of water on the bioplato and to justify the possibility of using filtration-regenerative bioplato hydroponic type (FRHTB) for the concomitant desalination of mineralized water using higher aquatic plants (HAP).

Research results. To substantiate the possibility of concomitant desalination of mineralized waters with the help of higher aquatic plants, phytotechnology of filtration-regeneration bioplato of hydroponic type was used, the basic scheme of which is shown in the figure.

According to the technological scheme of the filtrationregeneration bioplato hydroponic type (FRHTB) phytodesalination and water purification is carried out in several stages. The major degree of water desalination and purification occurs in the bioplot (1) itself through the use of photosynthesis processes in higher aquatic plants (HAP) with the absorption of salts and biogenic compounds from water and their accumulation in the biomass of higher aquatic plants. Thus, according to researches of V. Kravets [15] it is established that on the current systems of phyto-purification of water using higher aquatic plants, the removal of sulfates and chlorides on bioplato filters is $58-35 \%$ and $67-49 \%$, respectively, depending on the bioplato structure, from the time of year and species of higher aquatic plants. The total extraction of dissolved salts from mineralized water can be on average $40-55 \%$ of the total salt content of the original brackish water with a salt concentration of $2500-3500 \mathrm{mg} / \mathrm{dm}^{3}$.

An additional degree of desalination of mineralized (brackish) water according to the FRHTB technology is carried out by purification of water and concomitant extraction of salts from the circulation and regeneration waters of the bioplato with the use of reagents and probiotics in flotation reactor-clarifier (9) and then in self-flushing foam filter which are combined into a single water treatment complex [16]. Coagulants, metal hydroxides, filtration materials and suspensions of the natural minerals of clinoptilolite, kieselguhr, bruschet, tuff, bentonite, peat [17] and combinations thereof can be used for the purification and desalination of circulation-regeneration waters.

When using aluminum hydroxochloride coagulants with sodium aluminate to purify mineralized waters with a sulfate concentration of $500-700 \mathrm{mg} / \mathrm{dm}^{3}$, the degree of purification from sulfate reaches $83-88 \%$ [18]. Magnetite, iron and aluminum hydroxides obtained by electrolysis using metal anodes, known as the electrocoagulation process, have high sorption properties with respect to dissolved salts. Experimental data obtained by the authors show that when electrocoagulation the degree of chloride extraction from mineralized brackish water reaches $13-15 \%$, and sulfates $-20-31 \%$ and more due to the high sorption capacity of metal hydroxides at the time of their formation after ionization of metallic anodes by action electric current or internal electrolysis of metal chips $[19 ; 20]$. Probiotics [21] and activated natural suspensions based on zeolite (clinoptilolite) and other natural minerals or their complex mixtures [22] are dosed into the source water for intensification of photosynthesis processes in HAP with the assurance of a constant increase of green biomass in the bioplato.

Activation of the natural suspension of zeolite can be carried outby effectivemicroorganisms-enzymes, probiotics, and catholyte obtained in the cathode zone of the membrane cell $[19 ; 20]$, or by complex activation [23]. Suspension activation provides more intensive accumulation by zeolite and other natural filtration materials and suspensions of biogenic nitrogen and phosphorus compounds and stimulates intensive growth of the BBP root system, which promotes photosynthesis and the immobilization of salts by higher aquatic plants.

The technological scheme of purification and concomitant desalination of mineralized water in FRHTB works as follows. The mineralized water through the collector (8) is fed to the bioplato (1) and through the upper drainage (2) is evenly distributed in the upper layer of the filter backfill (3) where the most active suction zone of the root system of higher aquatic plants (12) is located.

Due to the constant contact of higher aquatic plants with water, active mass exchange between water and root system of HAP, photosynthesis in the bioplato complex biochemical processes of transformation of organic and mineral impurities present in water, absorption of dissolved salts by biomass of plants are occur are occur. The water is then filtered from top to bottom through the layers of the filter backfill $(3,4)$, uniformly collected through the filtration area by the lower drainage (6) and discharged as intended.

During the flow of water in the layers of the filter backfill and the root zone of the plants of the bioplate, there is a constant accumulation of film of activated sludge, microscopic algae, suspended mineral and organic impurities, which leads to the clogging of the layers of backfill and drainage. Increasing the hydraulic resistance of the filter layers, the suffusion processes begin to occur, which leads to a decrease in the quality of the purified water.

To prevent this process, some of the contaminated water is removed from the upper filter layer by means 
of a middle drainage (5), which ensures a constant regeneration of the upper layers of the filter backfill and the BBP root system. Initially, contaminated circulation and regeneration water is sent for further purification to the flotation reactor clarifier (9), where also supplies reagents for coagulation and sorption of the suspension and extraction of dissolved salts, as well as compressed air for flotation of the slurry and saturation of water by oxygen. The formed sludge and sediment are periodically withdrawn from the clarifier reactor (9). The purification of clarified water from the slurry is carried out on a foamed polystyrene filter (10). The filter backfill of the filter is periodically, as it is clogged, washed in hydro-automatic mode by means of a special siphon device (11). The flushing water is collected in a container (15) and then sent for purification into a flotation clarifier (10) together with circulation-regeneration water. If necessary, solutions of probiotics, enzymes and suspensions of effective microorganisms can be dosed into the purified circulation-regenerative water after the foam polystyrene filter. After purification in the bioflotation clarifierreactor (9) and in the self-washing polystyrene filter (10), the circulation-regeneration waters are mixed with the flow of the brackish water and fed into the "head" of the bioplato (1).

Thus, circulating-regenerating water throughout the day, circulating through the upper layer of the filter backfill (3) of the bioplato, repeatedly wash the root system of the BBP, which ensures their constant washing and allows to stabilize the process of purification and demineralization of brackish water in the FRHTB technology.

Depending on the degree of contamination and mineralization of the water, the complex block of FRHTB may work in some combined variants, in accordance with the specified operating modes of the system of purification and phytodesalination. At relatively high concentrations of contaminants and mineral salts, the entire stream of water can be fed directly into the flotation reactor-clarifier (9) and the selfwashing foam polystyrene filter (10) for pre-treatment and desalination before the bioplato in conjunction with circulating-regeneration water. At relatively average concentrations of contaminants, the water can be divided into two streams, one of which goes directly to the bioplato, and the other is mixed with circulating water and purified in a clarifier-reactor and a filter. The ratio of flows is determined by such parameters as the concentration of contaminants, the mode of flowes of water for purification, the requirements for the quality of purified and desalinated water, as well as the design of the bioplato.

The operating modes of FRHTB bioplato facilities also determine the types of reagents, the activated natural suspension, and the effective enzymes and probiotics that will be dosed or synthesized using a reagent farm (13). This allows you to adjust the properties of the water or change them in the direction required for the consumer of purified water, as well as to purify the water in any climatic conditions. In particular, with the help of reagents it is possible to remove especially toxic impurities (heavy metals, complex organic impurities of industrial character), to carry out the conditioning of purified water.

The FRHTB bioplato can be part of a general comprehensive scheme of physico-chemical technological scheme for water treatment. In this case, the bioplato may be placed at the beginning or end of the general scheme of contaminated water treatment. If the water contains high concentrations of readily oxidizable organic and mineral impurities and requires a deep reduction of mineralization, it is more appropriate to place the bioplato at the beginning of the technological scheme. This makes it possible to remove the bulk of organic and especially toxic mineral contaminants on the bioplato and to reduce the concentration of salts, and in the next stage to achieve a deep purification of clarified water. Placing the bioplato at the end of the technological scheme allows to provide deep purification of water from organic and inorganic impurities and restore its natural properties through contact with higher aquatic plants.

\section{Conclusions.}

Analysis of the possibility of phytodesalination of mineralized waters in filtration-regeneration bioplao of the FRHTB type shows:

1. Bioplato based on FRHTB technology can be used for hydro-automated purification and concomitant membrane-free phytodesalination of mineralized water. Phytodesalination of mineralized water in FRHTB is carried out by the extraction of salts by higher aquatic plants in the bioplato and the treatment of circulatingregenerative water with the help of coagulants, magnetite, metal hydroxides, suspension of natural minerals with additional electrochemical activation of reagents.

2. The unit for treatment and purification of circulation-regeneration waters of the bio-plato must include a flotation reactor-clarifier for introducing additional reagents and a self-washing foam polystyrene filter with dosage in clarified water of enzymes, bioreagents and probiotics, which allows for a steady increase in green biomass and intensify the extraction of salts by higher aquatic plants.

3. The calculations show that for the individual use of FRHTB total demineralization of brackish water with an initial salt concentration of $2500-3500 \mathrm{mg} / \mathrm{dm}^{3}$ can reach up to $40-60 \%$, depending on the design of FRBGT while providing the required degree of recirculationregeneration water.

4. The next stage of the work is the modeling of the process of complex purification and accompanying phyto-desalination of brackish water using the FRHTB technology and determination of the basic parameters of the functioning of the facilities of the technological scheme, depending on the degree of water recirculation and concentrations of contaminating components. 


\section{References}

1. Доповіді ООН щодо ситуації з правами людини (2014-2018). http://www.unwater.org/worldwaterday/about.html .

2. Державні санітарни норми та правила «Гігієнічні вимоги до води питної, призначеної для споживання людиною» (ДСанПіН 2.2.4-171-10). https://dbn.co.ua/load/normativy/sanpin/dsanpin_2_2_4_171_10_gigienichni_vimogi_do_vodi_ pitnoji priznachenoji_dlja spozhivannja ljudinoju/25-1-0-1180.

3. Хохрякова Е.А., Резник Я. Е. Водоподготовка. Справочник. / Под ред. д.т.н., С.Е. Беликова. М.: Изд. Дом «Аква-Терм:, 2007. 240 c. https://studylib.ru/doc/2279327/ vodopodgotovka---gaz.

4. Громов С., Пантелеев А., Сидоров А. Сравнение методов обессоливания воды. НПК «Медиана-Фильтр». http://www.mediana-filter.com.ua/ water_obessolivanie.html.

5. Куликов Н.И., Найманов А.Я., Омельченко Н.П., Чернышев В.Н. Теоретические основы очистки воды. Донецк: изд-во «Ноулидж», 2009. 298 с.

6. Является ли опреснение долгосрочным источником питьевой воды? FacePla.net. https://www.facepla.net/content-info/artmenu/627-is-desalination-long-term-way.html.

7. Greenway M. The role of constructed wetland in secondary effluent treatment and water reuse in subtropical and arid Australia. Ecological engineering, № 25, 2005, Р. 501-509.

8. Стольберг В.Ф., Ладыженский В.Н., Спирин А.И. Биоплато - эффективная малозатратная экотехнология очистки сточных вод // Екологія довкілля та безпека життедіяльності. № 3, 2003. С. 32-34.

9. Диренко А.А., Коцарь Е.М. Использование высших водных растений в практике очистки сточных вод и поверхностного стока // Сантехніка, опалення, кондиціювання. № 4. 2006. С. 12-15.

10. Петрук В. В., Кравець В.В. а ін. Споруда для очищення стічних вод з використанням вищих водних рослин. Патент № 3377. Бюл. № 11. 2004.

11. Василюк Т.П. Ефект очищення стічних вод біологічним методом з використанням рослин виду Eichornia crassipes за різного гідравлічного навантаження / Т.П. Василюк // Біотехнологія: науковий журнал. Київ, 2009. Вип. 1. С. 89-96.

12. Кропачева М.В. Высшие водные растения, как один из факторов самоочищения водоема. Известия Вузов. Пищевая технология. № 5-6, 2002, С. 78-79.

13. М.А. Захарченко, Рыжикова ИА, Яковлева Л.И. Опыт эксплуатации биоинженерных сооружений (БИС) типа Сonstructed Wetlands в Золочеве Харьковской области. Экология и здоровье человека. Охрана водного и воздушного бассейнов. ХІІ междунар. науч.-техн. конфер. Бердянск, 2004 г. Сб. научн. трудов. Харьков, 2004, Т-3, С. 557-561.

14. Bondar A, Fylypchuk V., Kuryliuk M., Ayaya Aniyefiok. Deep Purification of waters in filtration-regeneration bioplato of hydroponic type. Науково-практичний журнал «Екологічні науки». № 16-17, 2017. С. 39-45.

15. Кравець В.В. Гомологічний ряд вищих водяних рослин в системах глибокого доочищення і знезараження очищених стічних вод. Міжнародний конгрес і технічна виставка ЕТЕВК. м. Ялта, 2011, Збірка доповідей. С. 289-294.

16. Бондар О.І., Курилюк А.М., Филипчук В.Л., Курилюк М.С. та ін. Біоботанічний комплекс очищення води AQUABIOSYNERGY-74. Патент № 104080. Бюл. № 1. 2016.

17. Бондар О.І., Курилюк О.М., Курилюк М.С., Филипчук В.Л. та ін. С-модуль синергетичного очищення води ELION-U-SYNERGY.163-С. Патент № 94674. Бюл. № 22. 2014.

18. Рисухін В.В. Очищення від сульфатів вод з підвищеною мінералізацією і жорсткістю / В.В. Рисухін, Т.О. Шаблій, В.С. Камаєв, М.Д. Гомеля // Екологічна безпека. 2011. № 2. С. 70-75.

19. Филипчук В.Л. Очищення багатокомпонентних металвміщуючих стічних вод промислових підприємств. Рівне: УдУВГ, 2004. $232 \mathrm{c}$.

20. Rogov V., Kuriljuk N., Anopolsky V., Shvorob V., Moskalev I. Electrolyzer for removing fluorine-containing impurities from water. United States Patent Number 5,124,017-US005124017A.

21. Маркин В.В. Возможности интенсификации очистки городских сточных с помощью пробиотических средств. Комунальне господарство міст. 2014. Вип. 114. С. 131-135.

22. Бондар О.І., Курилюк О.М., Курилюк М.С., Филипчук В.Л. та ін. Синергетичний комплекс очищення води AQUA-U-ELION. Патент № 95617, Бюл. № 24. 2014.

23. Курилюк М.С., Кривошей П.П., Курилюк О.М., Филипчук В.Л. та ін. Фітоблок із Тесла-активатором води AQUA-T-SYNERGY-14UA. Патент № 101243, Бюл. № 16. 2015. 